\title{
Profile and behavior of elderly flower consumer in Paraná Coast ${ }^{(1)}$
}

\author{
ADILSON ANACLETO ${ }^{(2)}$, ERIKA SUMIKO FUJITA(2), LORRAINE PAES MENDES(2), \\ REGIANE MACENO VIEIRA ${ }^{(2)}$, RENNAN DE TARSO PEREIRA(2)
}

\begin{abstract}
The per capita consumption of flowers in Brazil has presented successive growth rates, although the consumption in consumer class called elderly, that is 60 years old or more, is still incipient when compared to other countries such as the United States, Japan and the most part of European countries where the consumption of these people is more than the double of consumption in Brazil. In this context, it is presented the results of the profile and consumer behavior evaluation of elderly flowers consumer, aiming to subsidize the establishment of marketing actions for the retail segment of the flower production chain. The study was accomplished using 169 interviews with elderly people of both genres at the time that they were buying flowers in 22 flower shops in Paraná Coast. The female gender was identified as the majority consumer $(p=78.7 \%)$. It was observed a tendency in the increase of consumption based on advanced schooling. It was registered an average of acquisition of 5,81 times per year, with preferential consumption of roses, violets and orchids. The accessibility to stores, the service quality followed by the high prices of flowers, were the main consumption limiting factors in the class evaluated.
\end{abstract}

Keywords: flowers trade, retail trade, agribusiness, ornamental plants.

\section{RESUMO}

Perfil e comportamento do consumidor de flores na terceira idade no litoral do Paraná

O consumo per capita de flores no Brasil tem apresentado sucessivas taxas de crescimento, porém, o consumo na classe de consumidores denominado de terceira idade, que possui 60 anos ou mais, ainda é incipiente quando comparado com outros países como os Estados Unidos, Japão e a maioria da dos países da Europa onde o consumo desta classe é mais que o dobro que no Brasil. Neste contexto, apresenta-se o resultado da avaliação perfil e do comportamento do consumidor de flores na terceira idade, visando subsidiar o estabelecimento de ações de marketing para o segmento comercial varejista da cadeia produtiva de floricultura. O estudo foi realizado a partir de entrevistas com169 idosos de ambos os gêneros no momento em que compravam flores em 22 floriculturas do litoral do Paraná. Identificou-se o gênero feminino como consumidor majoritário ( $p=78,7 \%)$. Observou-se tendência a elevação no consumo a medida que avançava a escolaridade. Registrou-se média de aquisição de 5,81 vezes ao ano, com consumo preferencial de rosas, violetas e orquídeas. A acessibilidade das lojas, a qualidade do atendimento seguido pelo elevado preço das flores, foram os maiores limitadores ao consumo na classe avaliada.

Palavras-chave: comércio de flores, comércio varejista, agronegócio, plantas ornamentais.

\section{INTRODUCTION}

In Brazil, the population classified as elderly is also called the third age, and similarly as observed in other countries, this population has increased when compared to the other age groups (IBGE, 2013).

The conception of elderly people class occurs by the nomination of the citizen aging process, linked to the rest and inactivity of the elderly, in Brazil it officially occurs at the 60 years old, as described in Law No. 10741 October 1, 2003 (BRASIL, 2014).

The recent medicine advances along with new and advanced technologies to the study and treatment of elderly people health, has generated according to IBGE (2013) a significant improvement in life expectancy of Brazilians, which only in the last decade increased 6.3 years.
According to IBGE (2013) the extension of the life expectancy of elderly, along with decrease in birth rate, determines that, in the year of 2030, the number of elderly people will be greater than the number of children up to 14 years and it will represent $33.7 \%$ of the total population in Brazil.

The class of elderly consumers has been changing gradually the trade scenario in Brazil, being a reality the influence of this class in all segments of consumption (SILVA and XAVIER, 2012). The 22.3 million of elderly consumers in Brazil will probably move values close to $\mathrm{R} \$$ 400 billion in 2015. (SEBRAE, 2015a).

Despite the commercial relevance of elderly consumers, there are few academic studies on the profile and behavior of them, in general and specifically in the case of flowers consumption, the information is even scarcer (BAKSHI,

DOI: http://dx.doi.org/10.14295/oh.v23i3.1029

${ }^{(1)}$ Received in 25/08/2017 and accepted in 25/09/2017

${ }^{(2)}$ State University of Paraná (UNESPAR), Department of Business Administration, Paranaguá-PR, Brazil. *Corresponding author: adilson.anacleto@ unespar.edu.br

Licensed by CC BY 4.0 
2012). It is important to highlight that retailers still give little attention to the elderly consumers, and a significant portion of the elderly financial income is intended for nonessential products such as flowers.

The flower trade has proved to be an important economic alternative in Brazil (CARVALHO et al., 2015), but despite the amount of $\mathrm{R} \$ 5.64$ billion, generated by the activity, when associated to the elderly, it does not show significant public accession (LANDGRAF and PAIVA, 2009; SEBRAE, 2015b; JUNQUEIRA and PEETZ, 2017).

In other nations where the flower market is more consolidated as the Netherlands, Germany, Japan, Italy, United States among other countries, the consumption of flowers by the elderly is classified as a niche market, given the high levels of this public consumption registered in these countries, noting the existence of a market orientation process by the retailers and wholesalers to the producers in order to direct the production of the species that can better meet the desires of this type of consumer (LANDGRAF and PAIVA, 2009; JUNQUEIRA and PEETZ, 2014; SEBRAE, 2015a). The annual average consumption per capita of flowers and ornamental plants is currently estimated at R\$ 26.27, much lower than the average of other countries (SEBRAE, 2015), but specifically related to the consumption of flowers by elderly class in Brazil, there are no data that reveal the average per capita, consumption habits, as well as what are the factors that can influence these spending habits.

According to Anacleto et al. (2014) the factors that influence consumer preferences in general are unknown, specifically those related to flowers and ornamental plants which studies are even more incipient. In this context, considering this lack of information and what types of flowers the elderly consumers wish, this study could propose a direction and orientation to the market and helping with information that could improve the commercialization of flowers, then this paper aimed to promote a diagnosis on flower consumption in the elderly, and sought to answer the following questions: a) Identify more means of annual consumption, and the most preferred flowers among the elderly consumers; b) Identify which socioeconomic factors such as gender, income, marital status and schooling could change the behavior of flower consumption in the evaluated class; c) Identify the main reasons for purchasing, as well as the main periods and dates of flower purchase by the elderly; d) Identify what factors could hinder the flowers consumption in this class of consumers.

\section{MATERIALS AND METHODS}

The study was accomplished with interviews with people belonging to the social classification known as elderly, whose individuals are 60 years old or more (BRASIL, 2014) in Paraná Coast.
The research developed in this paper can be characterized as exploratory-descriptive and it was employed the quantitative method with a questionnaire with 17 semi-structured questions and six open questions as the data collection instrument, which were applied between January and March of 2015. (SCHIMMENTI et al., 2013; ANACLETO et al., 2015).

The sample was composed with 169 elderly people, and answered the guidance of marketing research and consumer profile when the population is unknown. (MALHOTRA, 2010).

In order to be part of the sample and according to proposed by Anacleto and Negrelle (2013) and Anacleto et al. (2015), the elderly consumer should have bought flowers at least once in the last 12 months, and the consumer should show agreement in participating in research, without identifying.

The analysis of the data sought to identify among the investigated class, the existence of differences between the averages related to flowers consumption in function of these variables: education, family arrangement, income, age and marital status that were considered as explanatory factors, as proposed by Malhotra (2010) and Anacleto et al. (2014).

The age distribution was adopted according to IBGE (2013) and the classification of the economic condition in accordance with the Brazilian criterion (ABEP, 2017).

The normality of the data, in accordance with Hair et al. (2009) was analyzed by the Kolmogorov-Smirnov test by the level of $p<0.05$.

At first it was found the intensity of the relationship through correlation among the variables, similarly to the studies developed by Anacleto et al. (2014), and in order to assess the influence of gender, age, education, and economic condition on the flowers consumption levels, it was applied nonparametric tests of Mann-Whitney and Kruskal-Wallis followed by the multiple comparison test of the averages of Dunn, in a significance level of 5\% $(p<0.05)$.

The existence of correlation between the flowers consumption to the other variables it was analyzed by Spearman's rank correlation coefficient (HAIR et al., 2009).

The possible expansion of flowers consumption and the influence of the substitutes products were obtained through a hierarchical categorization which foresaw five indications of the most relevant factors.

\section{RESULTS AND DISCUSSION}

The overall average of flower purchases (Table 1) among elderly is 5.81 times per year, divided into flowers for own use $(\mathrm{M}=3.47$; $\mathrm{DP}=4.33)$, and as gift $(\mathrm{M}=2.34$; $\mathrm{DP}=2.88)$, with statistically significant differences $(p=$ $0.001)$. 
Table 1. Times that consumers bought flowers for use and as gift in the last 12 months $(n=169)$

\begin{tabular}{|c|c|c|c|c|}
\hline \multirow{2}{*}{$\begin{array}{l}\text { Number of times in the last } 12 \text { months } \\
\text { bought flowers }\end{array}$} & \multicolumn{2}{|c|}{ For own use } & \multicolumn{2}{|c|}{ As gift } \\
\hline & $\mathbf{N}$ & $\%$ & $\mathbf{n}$ & $\%$ \\
\hline None & 23 & $13.6 \%$ & 49 & $29.0 \%$ \\
\hline Between 1 and 2 times & 71 & $42.0 \%$ & 66 & $39.1 \%$ \\
\hline Between 3 and 4 times & 39 & $23.1 \%$ & 27 & $16.0 \%$ \\
\hline Between 5 and 6 times & 15 & $8.9 \%$ & 15 & $8.9 \%$ \\
\hline 7 or more times & 21 & $12.5 \%$ & 12 & $7.2 \%$ \\
\hline Average $(p=0.001)^{1}$ & \multicolumn{2}{|c|}{$3.47 \mathrm{~b}$} & \multicolumn{2}{|c|}{$2.34(b)$} \\
\hline Standard deviation & \multicolumn{2}{|c|}{4.33} & \multicolumn{2}{|c|}{2.88} \\
\hline
\end{tabular}

${ }^{1}$ Significance value of Wilcoxon test for paired samples. a,b Equal letters do not differ statistically from each other $p<0.05$.

The most investigated flower elderly consumer were females $(\mathrm{n}=78.7 \%)$, which had a higher frequency of purchasing $(\mathrm{M}=4.03 ; \mathrm{DP}=4.63)$ when the flowers were for their own use, showing significant statistically differences $(p$
$<0.001)$ relative to the men consumption $(\mathrm{M}=1.39$; $\mathrm{DP}=$ 1.86). However, when the flower purchase had the purpose to be given as gift, there were no significant differences $(p=$ 0.443 ) between the female and male individuals (Table 2).

Table 2. Comparison between genders related to the times the elderly consumers bought flowers for their own use and as gift in the last 12 months $(\mathrm{n}=169)$

\begin{tabular}{|c|c|c|c|c|}
\hline \multirow{2}{*}{ Gender } & \multicolumn{2}{|c|}{ For own use } & \multicolumn{2}{c|}{ As gift } \\
\hline Female $(\mathrm{n}=133)$ & Average & Standard deviation & Average & Standard deviation \\
\hline Male $(\mathrm{n}=36)$ & $4.03 \mathrm{a}$ & 4.63 & $2.38 \mathrm{a}$ & 2.85 \\
\hline Mann-Whitney test & $1.39 \mathrm{~b}$ & 1.86 & $2.19 \mathrm{a}$ & 2.82 \\
\hline
\end{tabular}

$\mathrm{p}$ - Significance value of Mann-Whitney test. a, b Equal letters do not differ statistically from each other $\mathrm{p}<0.05$.

Elderly women were the major consumers (Table 2) of flowers among the respondents, thus, according to Yue and Behe (2010) the consumer during purchase process experience acts as a result of various events already occurred, these influences in the case of flowers can be more evident due to the historical conditions of the woman, as provider of cleaning and decoration of domestic environments, by the sensitivity generated by visual aspect, since they consider the color and beauty of the flowers, as well as the perfume exhaled. These are factors that may become relevant influence points with these consumers and therefore decisive for their consumption.

According to Blackwell et al. (2006) and Urdan and Urdan (2010) internal factors are related to issues associated to the consumers mind when they are considered personal values, perception, needs and consumer lifestyle that can be originated from the childhood or being associated to the affective issues toward other people. Under this approach, the higher is the consumer experience the greater will be the cognitive, emotional and connotative perception concerning the purchase, and the greater will be the ability to analyze the relation of desired product benefits and its price, so the consumer behavior can be changed regarding to the minor resistance to the price, whether at the time of purchase experience the consumer realizes values that are classified as important. According to Blackwell et al. (2006) it is common in retail market stores use decoration with themes that refer to back to the past times, as a way of awakening the sensations experienced by consumers during the childhood period, since the reliving the sensations reduce for the consumer the price relevance, making this consumer more susceptible to the consumption.

The elderly between 70 and 74 years $(\mathrm{M}=4.47$; DP $=5.72$ ) had higher consumption of flowers than the other people evaluated, however there are no statistically significant differences in the number of purchases for use $(p=0.235)$ nor as gift $(p=0.886)$ (Table 3$)$, it is possible to say that the age for elderly consumer is not a factor that influence the number of flowers purchase per year. 
Table 3. Comparison between the times the consumers bought flowers for their own use and as gift in the last 12 months, by age group $(\mathrm{n}=169)$

\begin{tabular}{|c|c|c|c|c|}
\hline \multirow{2}{*}{ Genus } & \multicolumn{2}{|c|}{ For own use } & \multicolumn{3}{c|}{ As gift } \\
\hline 60-64 years $(\mathrm{n}=49)$ & Average & Standard deviation & Average & Standard deviation \\
\hline 65-69 years $(\mathrm{n}=40)$ & $3.63 \mathrm{a}$ & 4.82 & $2.57 \mathrm{a}$ & 3.67 \\
\hline 70-74 years $(\mathrm{n}=38)$ & $2.93 \mathrm{a}$ & 2.39 & $2.38 \mathrm{a}$ & 2.68 \\
\hline 75-79 years $(\mathrm{n}=24)$ & $4.47 \mathrm{a}$ & 5.72 & $2.00 \mathrm{a}$ & 1.86 \\
\hline$\geq 80$ years $(\mathrm{n}=18)$ & $3.21 \mathrm{a}$ & 3.62 & $2.08 \mathrm{a}$ & 2.54 \\
\hline Kruskal-Wallis test & $2.44 \mathrm{a}$ & 3.67 & $2.67 \mathrm{a}$ & 2.85 \\
\hline
\end{tabular}

$p$ - Significance value of Kruskal-Wallis test. ${ }^{\mathrm{a}, \mathrm{b}}$ Equal letters do not differ statistically from each other $\mathrm{p}<0.05$.

Although age has not been proved as a relevant factor in the consumption behavior of elderly consumer of flowers, according to Silva and Xavier (2012) the contemporary elderly, also known as "new elderly", i.e. those people who recently reached the third age, is more economically active than the old elderly, which according to the author, reinforces the idea that the market needs to fit to the new style of the elderly that among the many changes perceived
, has been modernized in the access to information with the popularization of the internet. The elderly education is a relevant factor in the consumption of flowers, as it has been observed statistically significant differences in both, the number of flowers purchase for use $(p=0.030)$ and as gift $(p=0.025)$, it was observed that as the elderly advances in education, higher is the number the flowers purchase over the past 12 months (Table 4).

Table 4. Comparison between the times the consumers bought flowers for their own use and as gift in the last 12 months, by educational level $(\mathrm{n}=169)$

\begin{tabular}{|ccccc|}
\hline \multicolumn{1}{|c}{ Genus } & \multicolumn{2}{c}{ For own use } & \multicolumn{2}{c}{ As gift } \\
\hline Illiterate $(\mathrm{n}=15)$ & Average & Standard deviation & Average & Standard deviation \\
\hline Elementary School $(\mathrm{n}=61)$ & $2.47 \mathrm{a}$ & 3.48 & $1,27 \mathrm{a}$ & 2.28 \\
\hline High school $(\mathrm{n}=57)$ & $2.05 \mathrm{a}$ & 2.25 & $2.08 \mathrm{~b}$ & 2.24 \\
\hline Graduation $(\mathrm{n}=28)$ & $2.74 \mathrm{~b}$ & 3.86 & $2.21 \mathrm{~b}$ & 2.62 \\
\hline Post-graduation $(\mathrm{n}=8)$ & $\mathrm{c} 3.57$ & 4.18 & $3.04 \mathrm{~b}$ & 3.82 \\
\hline Kruskal-Wallis test & $4.50 \mathrm{c}$ & 3.54 & $4.75 \mathrm{c}$ & 4.10 \\
\hline
\end{tabular}

$p$ - Significance value of Kruskal-Wallis test. a, b, $\mathbf{c}$ Equal letters do not differ statistically from each other $(p>0,05$ in the test of multiple comparisons according Dunn procedure).

Education shows significant differences in flowers consumption for elderly (Table 4), as it raises consumption also raises. The consumers with higher education, due to the cultural capital, influence the consumers of less education classes who tend to exercise the principle of imitation of the classes of consumers who are opinion formers (KOTLER and KELLER, 2011). The influences of the classes such as education, income among others in elderly, have occurred quite sharply. According to Silva and Xavier (2012) the contemporary elderly has developed the habit of participating in elderly clubs and elderly social attention centers, where coexistence is daily, the interrelationships and influences by opinion leaders is established on the circles of conversation and trips often carried out in these spaces of collective experience.

The consumer influence with higher level of education will only occur if this person feels higher level of satisfaction with the flowers purchased. According to Kotler (2011) the satisfaction with the purchase is an exchange process made by a process of value creation between two parts. If the value obtained is interesting for both parts involved, then there is a process called transaction and in this way, the higher is the elderly customer satisfaction, the greater is the feeling of the desire attended, which refers to consumer loyalty in relation to the product and the place of commerce. It was observed that if the indexes of elderly consumers' satisfaction were raise the elderly could become a loyal consumer.

The marital status of the consumer apparently is not an influence factor on flowers consumption, because despite the research reveals that single people have higher average annual consumption, the differences in relation to other groups are not significant nor on the number of flowers purchasing for own use $(p=0.897)$ nor as gift $(p=0.409)$ (Table 5). 
Table 5. Comparison between the times the consumers bought flowers for their own use and as gift in the last 12 months, by marital status $(n=169)$

\begin{tabular}{|c|c|c|c|c|}
\hline \multirow{2}{*}{ Genus } & \multicolumn{2}{|c|}{ For own use } & \multicolumn{2}{c|}{ As gift } \\
\hline Single $(\mathrm{n}=7)$ & Average & Standard deviation & Average & Standard deviation \\
\hline Married $(\mathrm{n}=72)$ & $4.86 \mathrm{a}$ & 7.40 & $4.43 \mathrm{a}$ & 7.07 \\
\hline Divorced $(\mathrm{n}=18)$ & $3.35 \mathrm{a}$ & 4.60 & $2.51 \mathrm{a}$ & 2.53 \\
\hline widower $(\mathrm{n}=72)$ & $3.56 \mathrm{a}$ & 3.24 & $2.67 \mathrm{a}$ & 3.56 \\
\hline Kruskal-Wallis test & $3.33 \mathrm{a}$ & 3.94 & $1.88 \mathrm{a}$ & 2.16 \\
\hline
\end{tabular}

$\mathrm{p}$ - Significance value of Kruskal-Wallis test. a, b Equal letters do not differ statistically from each other $\mathrm{p}<0.05$.

As regards to the monthly family income, statistically significant differences were observed in the number of flowers purchasing per year, both for own use $(p=$
$0.084)$ as gift $(p=0.005)$, being the increase of flowers consumption related to the increase of monthly family income (Table 6).

Table 6. Comparison between the times the consumers bought flowers for their own use and as gift in the last 12 months, considering the monthly family income $(\mathrm{n}=169)$

\begin{tabular}{|c|c|c|c|c|}
\hline \multirow{2}{*}{ Gender } & \multicolumn{2}{|c|}{ For own use } & \multicolumn{2}{|r|}{ As gift } \\
\hline & Average & Standard deviation & Average & Standard deviation \\
\hline Up to $\mathrm{R} \$ 1,349(\mathrm{n}=56)$ & $2.75 \mathrm{a}$ & 3.04 & 1.41 the & 1.69 \\
\hline From 1,350 to $2249 \mathrm{R} \$ \mathrm{R} \$(\mathrm{n}=37)$ & $2.92 \mathrm{ab}$ & 2.63 & $1.95 \mathrm{ab}$ & 2.09 \\
\hline From 2250 to $3,999 \mathrm{R} \$ \mathrm{R} \$(\mathrm{n}=39)$ & $4.51 \mathrm{ab}$ & 5.75 & $2.56 \mathrm{bc}$ & 2.31 \\
\hline Of the $4,0007799 \mathrm{R} \$ \mathrm{R} \$(\mathrm{n}=25)$ & ab 3.04 & 4.88 & $3.32 \mathrm{acd}$ & 3.34 \\
\hline Over $7,800 R \$(n=12)$ & $6.00 \mathrm{c}$ & 6.06 & $5.08(d)$ & 5.98 \\
\hline Kruskal-Wallis test & \multicolumn{2}{|r|}{$p=0.084$} & \multicolumn{2}{|r|}{$p=0.005$} \\
\hline
\end{tabular}

$p$ - Significance value of Kruskal-Wallis test.

a, b,, $\mathbf{c}$ d Equal letters do not differ statistically from each other ( $p>0,05$ in the test of multiple comparisons according Dunn procedure)

Related to the flowers purpose and use, the purchases were aimed at greater relevance for the decoration of family members graves (Table 7).
The research revealed that the birthdays of people close to the elderly was the main reason for buying flowers as a gift (Table 8).

Table 7. Main motivating factors of buying flowers on the coast of Paraná by consumers of the old age $(n=169)$.

\begin{tabular}{|c|c|c|}
\hline & Motivating factors & Relevance Index \\
\hline 1 & Grave decoration & 114 \\
\hline 2 & House/home decoration & 75 \\
\hline 3 & Garden decoration & 62 \\
\hline 4 & Office Decoration & 11 \\
\hline
\end{tabular}

Question with simultaneous choices 
Table 8. Main dates on which elderly consumers used to buy flowers in Paraná Coast $(n=169)$

\begin{tabular}{|c|c|c|}
\hline & Special dates & Index of relevance \\
\hline 1 & Birthday & 91 \\
\hline 2 & Personal achievements of loved ones & 35 \\
\hline 3 & Wedding & 26 \\
\hline 4 & Women's day & 13 \\
\hline 5 & Graduation & 21 \\
\hline 6 & Easter & 8 \\
\hline 7 & Apology & 8 \\
\hline 8 & Seduction & 6 \\
\hline
\end{tabular}

Question with simultaneous choices

Roses, orchids and violets were the species most cited by elderly class when they buy, both for their own use and as a gift (Table 9).
It was evidenced that the main factors that would lead the elderly consumer to buy more flowers were the price, greater flowers variety and greater amount of flower shops (Table 10).

Table 9. Flowers species preferred by elderly consumer in Paraná Coast $(n=169)$.

\begin{tabular}{|c|c|c|c|c|c|}
\hline & Flowers for own use & Relevance index & & Flowers as gift & Relevance index \\
\hline 1 & Roses & 215 & 1 & Roses \\
\hline 2 & Violets & 102 & 2 & Orchids & 273 \\
\hline 3 & Orchids & 72 & 3 & Violet & 112 \\
\hline 4 & Chrysanthemum & 67 & 4 & Daisies & 43 \\
\hline 5 & Daisy & 67 & 5 & Chrysanthemum & 40 \\
\hline 6 & Carnation & 42 & 6 & Lilies & 26 \\
\hline 7 & Lily & 27 & 7 & Sunflower & 17 \\
\hline 9 & Azalea & 15 & 8 & Carnation & 17 \\
\hline 10 & Sunflower & 13 & 9 & Tulip & 12 \\
\hline
\end{tabular}

Question with simultaneous choices

Table 10. Main factors that hinder the flowers purchase of elderly consumers in Paraná Coast $(n=169)$

\begin{tabular}{|c||c|c|}
\hline \multicolumn{2}{|c|}{ Main factors that hinder to enlarge the consumption } & Relevance Index \\
\hline 1 & Very high price & 122 \\
\hline 2 & Little variety of flowers in stores & 62 \\
\hline 3 & Few flowers shop & 29 \\
\hline 4 & Low quality of service & 29 \\
\hline 5 & Flowers quality & 25 \\
\hline 6 & Acessibility to the stores & 29 \\
\hline 7 & Unattractive promotions & 21 \\
\hline 8 & Difficulty to find flowers in greater quantity \\
\hline 9 & Do not find the desired flower & 10 \\
\hline 10 & Purchasing power & 9 \\
\hline
\end{tabular}

Question with simultaneous choices 
The majority part of the flowers shops showed inadequacies to this class of consumers due to the difficulty of accessibility to shops and the inexistence of parking lots in nearby, in addition to what was mentioned, the lack of places to accommodate themselves inside the store during the purchase period. According to Blackwell et al. (2006) consumers in this category typically devote greater time in the buying process, and usually they require special conditions, thus offer to this class of customers a receptive environment and with good accessibility may make them feel valued, this factor harnessed to the information in accessible language to the client in order to make them understand the benefits of the correct forms of flowers cultivation and treatment that extend the durability of the flowers may elevate the perception of them about the quality of the product, and it can also reduce the negative impacts of the price issue in the sales approach and can also reduce the negative impacts of the price issue in the sales approach.

The observation to the details in the customer service can be decisive, second in the process of consumption expansion, according to Kotler and Keller (2011) despite the changing preferences of the consumer and increasing competition, the companies must maintain or improve their quality and measure the consumer satisfaction regularly, highlighting the importance of post-purchase as a customer loyalty tool. Kotler and Keller (2011) affirm that the elderly client tends to loyalty, though a set of trade policies in the retail market could make this process easier. According to Blackwell et al. (2006) and Anacleto et al. (2015) the elderly consumer appreciates the benefits obtained in the process of customer loyalty, for example: the offering of a loyalty card, which provides the consumer a differentiated service in accredited stores and exclusive discounts, thereby increasing the frequency in the shops by creating a link between the trader and the consumer, being an important marketing tool. In order to this loyalty occurs, businessmen and shopkeepers have to adapt their establishments to this consumer and attend to their special needs, as in the physical aspect of the place as in the service.

Different from other consumers, the elderly class has more free time to go through the stores out and check the shelves, and that is why they give a lot of importance to a good service (KOTLER, 2011). This consumer wants to be served with respect, patience and cordiality, therefore, it is highlighted the importance of well preparing the sellers for this kind of service. The investment in training the sellers for this kind of client can represent an alternative to increase the sales along with this class.

Performing adjustments and tweaks for the physical and internal layout of the flower shops in order to offer to this class comfort, places to rest inside the stores, accessibility ramps for wheelchair users, own parking lot and even better store lighting, and home deliveries with no cost to the consumer of this class can be seen as differentials to the consumers who realize that their interests and needs are being met, thus building solid business relationships in a market segment with great growth potential in Brazil. According to Anacleto et al. (2014), in a globalized trade scale experienced by the currently flowers market, it is essential that retailers know the factors that influence the elderly consumer age preference, and thus can be able to define strategic actions aiming a market positioning and for that, a guidance from retailers to producers is an essential condition of regional development. The information about what are the consumer preferences in relation to a product must guide the flowers production lines in the field, resulting in the expansion of commercialization capacity and product demand (KOTLER, 2011).

Thus, the greater or lesser flow of the flowers crop depends on the sense of gain and satisfaction after purchase experienced by the collective consumer, because it is derived from the buying felling, which arises the perception of disparity between expectation and satisfaction with the acquired flowers. In this context if the evaluation is positive, the future consumers will feel the desire of repurchasing flowers, however if the assessment is negative, the discomfort will make the consumers reject the flowers in the future or yet this consumer will search for a product that will replace the flowers.

It is important to observe that the interaction between the actors is an essential condition in the process of new approaches development that aim the regional development of the flower trade, since it can point to the needs of the adjustments, corrections of logistics and technological changes that can generate consumer information. Thus, the dialogue of the actors involved in the flower trade, namely, retailers and elderly consumers, can guide production in the field. This interlocution can be more easily obtained by the scientific community, especially in universities, as also described by Weber (1987), who reports that the understanding of the problematization experienced by a society must also be observed as the responsibility of science, which must seek the interpretative understanding of the social action and an explanation of its origins and causes, as well as its effects. The great challenge of science must be to solve the problems existing in society for society, and therefore the need for a debate between science and other interlocutors searching for a new vision that together can strengthen the regional flower production chain.

\section{CONCLUSIONS}

The research pointed out that the average of flowers purchases among the elderly consumers is 5.81 times per year, being that women were the majority of consumers who purchased them $(n=78.7 \%)$, being the most important species the roses, orchids and violets, as for their own use and as gift, there was the same similarity.

The elderly education and the monthly family income were factors associated to flowers consumption, it was observed statistically significant differences as the education and income increased, the purchasing power increased both for flowers, as well as some substitute products also.

The main reasons that lead an elderly consumer to buy flowers are the graves decoration, home and house decoration and their outside gardens. Related to purchase at special dates, it was highlighted birthdays, personal achievements of loved ones and weddings. As regards 
to the flowers as birthday gifts were the occasion more pointed by the interviewed people. Accessibility to the stores, the quality of srvice followed by the high price of flowers, were the largest limiters to consumption. The results show that the most part of respondents were women, so the research presents as a limitation the need to study further ways in future surveys as a way of encouraging research that is still restricted on the retail market and that must also be attentive to the elderly male audience who revealed low participation in purchases and may represent significant sales growth rates.

\section{REFERENCES}

ANACLETO, A.; FUJITA, E.S.; MENDES, L.P.; VIEIRA, R.M.; PEREIRA, R.T. Influence of the 4Ps in the buying behavior of elderly consumers flowers in Paraná Coast Brazil. International Journal of Engineering Research \& Science, v.1, n.9, p.119-125, 2015.

ANACLETO, A.; NEGRELle, R. R. B. Produção de bromélias no Estado do Paraná, Brasil. Ornamental Horticulture, v.19, n.2, p.121-136, 2013.

ANACLETO, A.; NEGRELLE, R.R.B.; MURARO, D.; TOYOFUKU, T.M. Profile and behavior of the Bromeliads consumer in Paraná State - Brazil. Business Management Review, v.5, n.1, p.12-19, 2014.

ABEP - Associação Brasileira de Empresas de Pesquisa. Critério de classificação econômica Brasil. Available in: $<$ www.abep.org $>$. Accessed in: November $26^{\text {th }} 2013$.

BAKSHI, S. Impact of gender on consumer purchase behaviour. Journal of Research in Commerce and Management, v.1, n.1, p.1-8, 2012.

BLACKWELL, R.D.; ENGEL, J.F.; MINIARD, P.W. Consumer behavior. 10ed. South Wester: Ohio, 2006. 832 .

BRASIL. Presidência da República, Casa Civil: Subchefia para Assuntos Jurídicos. Estatuto do Idoso (2013). Available in: <http://www.planalto.gov.br/ccivil_03/ Leis/2003/L10.741.htm>. Accessed in: November 10th 2014.

CARVALHO, L.; PAIVA, P.D.O.; SANTOS, A.C. Flower and ornamental plants wholesale markets in Brazil. Ornamental Horticulture, v.21, n.1, p.53-62, 2015.

HAIR, J.R.; ANDERSON, R.E.; TATHAM, R.L., BLACK, W.C. Análise multivariada de dados. 6ed. Porto Alegre: Bookman, 2009.
IBGE. Estudos \& Pesquisas: informação demográfica e socioeconômica, síntese de indicadores sociais, uma análise de vida da população brasileira. Rio de janeiro: IBGE, 2013. 260p.

JUNQUEIRA, A.H.; PEETZ, M.S. O setor produtivo de flores e plantas ornamentais do Brasil, no período de 2008 a 2013: atualizações, balanços e perspectivas. Revista Brasileira de Horticultura Ornamental, v.20, n.2, p.115120, 2014.

JUNQUEIRA, A.H.; PEETZ, M.S. Brazilian consumption of flowers and ornamental plants: habits, practices and trends, Ornamental Horticulture, v.23, n.2, p.178-184, 2017.

KOTLER, P. Reinventing marketing to manage the environmental imperative. Journal of Marketing, v.75, p.132-135, 2011.

KOTLER, P.; KELLER, K. Marketing Management. New Jersey: Prentice-Hall, 2011. 816p.

LANDGRAF, P.R.C.; PAIVA, P.D.O. Produção de flores cortadas no Estado de Minas Gerais. Ciência e Agrotecnologia, v.33, n.1, p.120-126, 2009.

MALHOTRA, N. K. Marketing research: an applied orientation. Upper Saddle River: Pearson, 2010.

SCHIMMENTI, E.; GALATI, A.; BORSELLINO, V.; IEVOLI, C.; LUPI, C.; TINERVIA, S. Behaviour of consumers of conventional and organic flowers and ornamental plants in Italy. Horticultural Science, v.40, n.4, p.162-171, 2013.

SEBRAE. Flores e Plantas Ornamentais do Brasil. Brasília: Sebrae, v.1, n.1, 2015a. 42p.

SEBRAE. Flores e Plantas Ornamentais do Brasil. Brasília: Sebrae, v.1, n.2, 2015b. 96p.

SEBRAE. Flores e Plantas Ornamentais do Brasil. Série Estudos Mercadológicos. Sebrae, v.2, 2015. 100p.

SILVA, N.N.L.; XAVIER, M.P. A Terceira idade como foco das propagandas midiáticas de consumo. Psicologia em Revista, v.21, n.2, p.203-215, 2012

URDAN, A.T.; URDAN, F.T. Marketing estratégico no Brasil: teoria e aplicações. São Paulo: Editora Atlas, 2010. p.344.

YUE, C.; BEHE, B.K. Consumer color preferences for single-stem cut flowers on calendar holidays and non calendar occasions. Horticultural Science, v.45, n.1, p.78$82,2010$. 